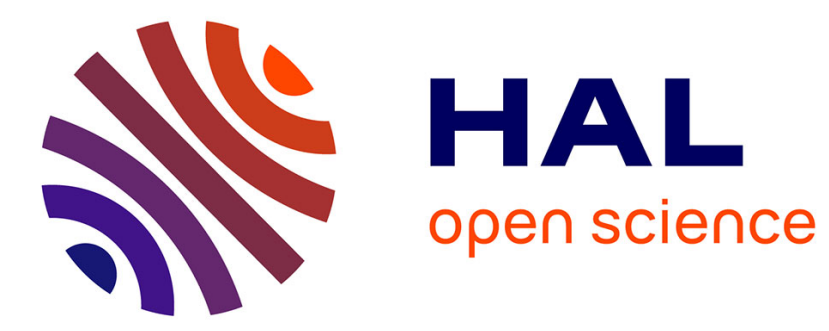

\title{
Erratum : Damping of the spin wave resonance by dislocations.
}

\author{
J. Morkowski
}

\section{To cite this version:}

J. Morkowski. Erratum: Damping of the spin wave resonance by dislocations.. Journal de Physique Lettres, 1975, 36 (2), pp.48-48. 10.1051/jphyslet:0197500360204800 . jpa-00231151

\section{HAL Id: jpa-00231151 https://hal.science/jpa-00231151}

Submitted on 1 Jan 1975

HAL is a multi-disciplinary open access archive for the deposit and dissemination of scientific research documents, whether they are published or not. The documents may come from teaching and research institutions in France or abroad, or from public or private research centers.
L'archive ouverte pluridisciplinaire HAL, est destinée au dépôt et à la diffusion de documents scientifiques de niveau recherche, publiés ou non, émanant des établissements d'enseignement et de recherche français ou étrangers, des laboratoires publics ou privés. 


\section{ERRATUM}

J. Physique Lett. 35 (1974) L-257

Damping of the spin wave resonance by dislocations.

\section{J. MORKOWSKI}

Page L-259, première ligne : lire $b=2.5 \AA$ au lieu de $b=3 \AA$. 